\title{
ANATOMY OF FOREIGN AID TO ETHIOPIA: 1960-2003
}

\author{
Adugna Lemi*
}

\begin{abstract}
The purpose of this study is to present a portrait of the foreign aid flow to Ethiopia during the 1960 to 2003 period. Since the launch of Marshal Plan after World War II, the flow of foreign aid has been seen as the panacea to overcome underdevelopment. Ethiopia is not an exception to this view, and Ethiopia is one of the recipients of foreign aid not only to provide emergency relief but also to support long-term economic development. This study shows the flow of aid to Ethiopia in terms of major donors (bilateral and multilateral), method of delivery, and major recipient sectors/purposes. The study attempts to answer the following questions: Which are the major donor countries? For what purposes has the aid been given? For which sectors has the country been receiving aid? Further, during the study period the country has twice experienced changes in government. How have the composition, donors, and purposes of aid changed with the changes of government? The paper attempts to present aid flows for the country's three government regimes. The study will use detailed aid data collected from donors by the OECD and recently made available. This study does not attempt to link the flow of aid to the progress, economic or otherwise, that has ensued from the flow of aid.
\end{abstract}

Key words: Foreign Aid, Ethiopia, Development JEL Code: F3, H2

*Adugna Lemi, Ph.D. Assistant Professor, Department of Economics, University of Massachusetts Boston

Boston, MA 02125, Email: Adugna.lemi@umb.edu 


\section{Introduction}

In 2005, the Gross Domestic Product of Ethiopia reached 74.5 billion Birr ( $\$ 8.6$ billion USD) ${ }^{1}$. During the same year, the economy grew at $8.8 \%$ compared to previous year. In five years (between 2000 and 2005), the economy added over 14 billion birr ( $\$ 1.6$ billion USD). At the aggregate, this is significant improvement for a country with the frequent climate calamites and poor infrastructure. Per capita wise, the same improvement may not be evident and Ethiopia remains on the lower step of the ladder that helps climb the hill of development. With the optimistic population estimate of 73 million people in 2005, the per capita income of the country was 1020 birr (\$117 USD) (IMF, 2006). This number is the lowest in the world in any standard. Various explanations can be posed for the limited improvement (per capita wise) of the economy ranging from liberalization (globalization) to population growth not only for Ethiopia but also for similar economies around the world. Aid inflow has been advocated for as one of the panaceas since 1950s, nevertheless, results of recent studies and reports is, at best, mixed.

Along with the growth in the overall economy comes increased government spending and deficit financing. The government collected about $\$ 2.3$ billion dollars including taxes and grants during 2004/2005 fiscal year. Out of which, $\$ 0.5$ billion dollars (22\%) was in the form of grants. During the same year, the government spent $\$ 2.8$ billion dollars and hence the revenue, including grants, was short of total expenditure by $\$ 0.6$ billion dollars. With out grants the deficit could have been about $\$ 1$ billion dollars. This makes the grant element of government's total expenditure $21 \%(\$ 0.6 / \$ 2.8)$. Of the $22 \%$ external grant that constitute part

\footnotetext{
${ }^{1}$ At that time, the exchange rate was $\$ 1=8.65$ birr.
} 
of government revenue, $50 \%$ comes in the form of grants in kind (or earmarked) and the remaining $50 \%$ comes in the form of untied cash (IMF, 2006).

How did the government finance the deficit? In principle, government could use both domestic and external sources of finance that a country can tap to finance the deficit. What is relevant for countries like Ethiopia is to finance deficits through hard currency since significant part of the financing is required to cover expenses spent in hard currencies to import essential goods. To this effect, external borrowing to finance the deficit accounts for $41 \%$ of total deficit during 2004/2005 fiscal year. The remaining sources of financing come from domestic borrowing and privatization revenue ${ }^{2}$.

Overall, the country depends on external source of finance for about $29 \%$ of its total government spending. As stated above, 19\% comes in the form of budgetary support grant and the remaining $10 \%$ comes as external borrowing. Arguments in favor of more grants than loans seem to have been practiced in Ethiopia at least during the early 2000s. Aid in the form of grant has been preferred over loans for several reasons (Rogoff, 2005, Bulow and Rogoff, 2005). Grant-only aid has been supported to prevent future debt crisis and to lift the tax burden from the week economies of recipient countries. It is also argued that grant-only approach will eliminate the "bad cop" role of development banks in enforcing debt payments. Clement and et. al. (2004), on the other hand, despised the idea of grant-only aid due to its negative implications on the collection of domestic revenue. Their study reveals that an increase in aid inflow in the form of grant is associated with a decrease in domestic revenue collection, which

\footnotetext{
${ }^{2}$ Note that privatization receipts used account for the larger share during the late 1990s but its role declined in recent years since most public enterprises have either been privatized or government decides to hold on to them.
} 
eventually strain government budget. Both lines of arguments qualify their respective conclusions with the need to enhance domestic institutions to respond to domestic revenue collection capacities but also to improve transparency in the operation of governments.

Whether the sources of financing is something to worry about depends on who gives us the grants, for what purposes they give us, when they give us, and whether we can count on them at all times. If the sources are predictable and do not depend on regimes, one can plan accordingly to make long-term plans. Otherwise, it is difficult to make progress in development with sporadic flow of money now and then. It is important for the predictability of the aid money to look at not only which countries account for the larger share of official bilateral flows and which aid agencies account for the larger share of multilateral creditors but also for what purposes the country has been receiving aid. Did they have preferences for any particular regime over the other? Do the national interests of the donors affect the pattern of aid flow into the country?

The purpose of this paper, therefore, is to look into the profile of the aid flow in to the country during 1960-2003. Special attention is given to the following questions. Who is giving when? Who is giving for what purpose/sector? Who is giving and in what form? Whose aid support/ killed the agricultural sector of the country? The aim is to present a draft portrait of aid flow to the country; no attempt is made to relate flows of aid to the performance of the economy, or no attempt is made to show the effectiveness of the aid flow. The remaining sections are divided as follows: the next chapter will present sources of data and methodology used in the paper, section three background information, and data on the flow of aid to the country; sections four 
and five give detailed account of the major donors and sector distribution of aid, respectively; the last section concludes the paper.

\section{Data Sources and Methods}

The Organization for Economic Cooperation and Development (OECD) has collected aid data from its members through its Development Assistant Committee (DAC) and Creditors Reporting System (CRS) questionnaires issued by the OECD secretariat. The data covers aid flows from DAC member countries who were members in 2003. List of member countries are indicated in appendix. The data on the geographic distribution of financial flows report for each recipient country from each DAC member countries individually, and from multilateral agencies from 1960 to 2003. Flows are grouped as loans, grants, technical cooperation, food aid, private flows, and other official flows. The private flows mainly include export credits, portfolio investments, and foreign direct investments. Both disbursement and commitment information are reported for all categories. Actual disbursement amounts are used for the analysis in this paper. This data set provides complete reporting from all donors (bilateral and multilateral) to all the recipient countries (OECD, 2005). For the purpose of this paper, only aid flow data for all donors to Ethiopia is employed.

Responses to the CRS questionnaire have sectoral distribution of only bilateral aid commitments from 1973 to 2003 . The sectors in this dataset refer to sectors of the recipient countries and not the type of goods or services provided. For details on the description of the sectors used in the reporting, refer to the appendix. Unlike the geographic distribution of 
financial flows data, the sectoral distribution data report incomplete inflrmation from the donors. Some of the member countries report the sectoral distribution of the aid flow only since 2002 (Greece and New Zealand). Data on technical cooperation by sector had not been reported by some of the member countries (Germany, France, Japan, and Portugal). Some Aid agencies of the United States prior to 1999 did not report their activities to the CRS. This makes the coverage of CRS aid data less than $100 \%$. The coverage ratio is $77 \%$ in 1995 but improved overtime as countries started reporting sectoral allocation of their aid. The coverage reached over $90 \%$ since 1999 . This makes it difficult to compare this data set with the geographic distribution data set described above. Obviously, the CRS data underestimates the aid flow not only for each sector but also for the total inflow. Nevertheless, even with the caveats, one can use this data as an approximation especially after 1999. In this paper, since coverage ratio of multilateral aid distributions are low, only bilateral aid distributions are employed.

The methods used to analysis the aid data are lowess, which is local regression smoothing, and simply bar graphs. Lowess is derived from the term "locally weighted scatter plot smooth," as both methods use locally weighted linear regression to smooth data. The smoothing process is considered local because each smoothed value is determined by neighboring data points defined within the span. The process is weighted because a regression weight function is defined for the data points contained within the span. Bar graphs are used to compare aid flows by donors- multilateral and bilateral - across regimes, sectors, and forms (type) of aid flows to Ethiopia. Comparisons are made in terms of both average flows and total flows for each donor, regime, sector, and forms of flows. With few exceptions, there is no variation in trends whether 
one looks into the average flows or the total flows for each donor for the geographic distribution aid data. For the sectoral distribution data, since coverage ratios are less than $100 \%$, only average aid flows are reported in all cases, for obvious reason that total aid inflows would be misleading.

\section{Background on Aid Flows and Donors}

There is no doubt that Ethiopia has been and is being used as a poster child (for international organizations, NGOs and recently rock bands) to generate aid money. Two famines that devastated the northern part of the country in 1970s and 1980s that still resonates among the public in the West prompted altruistic activities. The two world-wide music events (live-aid and live8), to garner millions of aid money from official and private donors, made it clear that

aid money is not just to develop a country in the long-run but to save life that needs emergency assistances. Credit goes to those who sponsored, organized, and contributed to those events to help save life of those in need at the time of emergency. While providing urgent needs, the country and international good-wishers should look across the horizon to provide sustainable support mechanism for the people.

Various key reasons have been forwarded to explain the dismal nature of the economy. At the same time alternatives mechanism have been suggested to tackle the problem once and for all. Some commentators argue that restrictive religious practice is to blame for it forces the people to stay home for almost half of the time during a given month. They went further to suggest that the country needs not only additional support in the form of aid but also a new calendar 
(Wiedemann, 2005). While other question the long-term contribution of aid that comes into the country. For instance, McLaughlin (2004) argues that because of the direct effect of food aid from U.S. cooking-oil industry in the Ethiopia had to shut down. There are other similar anecdotes that highlight the need for more aid and at the same time the need for restraint on aid to protect local economy.

There is also other concern with respect to aid flow: debt burden. As it is happening in other part of the world, aid in the form of loan - in cash or in kind - has implications on debt crisis. Although Ethiopia is not at an alarming rate with this regard, one needs to look into the current state of the debt burden for reference purposes. As of 2005 , the country owed over $\$ 6$ billion dollars to its creditors. Of this, $81 \%$ ( $\$ 4.9$ billion dollars) is owed to multilateral creditors, 13 $\%$ ( $\$ 0.8$ billion dollars) is owed to official bilateral donors and the remaining $5.9 \%$ is owed to other commercial creditors. Of the multilateral creditors, International Development Association (IDA), which is the World Bank group, accounts for about $70 \%$ of the debt stock; whereas International Monetary Fund (IMF) accounts for only 3.4\%. The African Development Bank/Fund accounts for 22\% of the debt stock. Paris Club member creditors account for $29 \%$ of the total debt stock that the country owed to official bilateral creditors. The remaining is owed to other official bilateral creditors. As one can see in the later sections, current aid inflows include debt relief provided to Ethiopia under different programs. It is important to keep this in mind to appreciate the significance of who is giving aid in the form of debt relief and in the form of fresh aid inflow. 
There are previous studies that document the profile of debt burden of and aid flow to Ethiopia. For instance, Alemayehu (2003) provides detailed account of the historic origin of Ethiopia's debt; Berhanu (2001) documents the level, source, and composition of aid flow into the country; Yamano, et. al (2003) presents the role food aid in rural Ethiopia, whereas Maxwell (1996) investigates the effectiveness of European aid to Ethiopia. Although the sprit of this current study and previous studies is the same - to document the profile of aid flow, this study not only uses latest and more detailed data but also presents aid flow by regime, type of aid and purpose of aid that the country has been receiving since 1960 .

Now let us turn to what has happened in terms of overall aid flow during the past four decades. Average aid flow to the country reached its peak in early 1990s and early 2000s (Figure 1). Increased trend in aid flow discontinued in mid 1990s and reached its trough point during the years of Ethio-Eritrea war (1997-2000). Similar trend applies when taking the sum of aid flows over all forms of flows and over all multilateral donors. In terms of the average aid flow over bilateral donors ${ }^{3}$, the same trend is observed albeit with less dramatic fluctuations during regime changes and war times. Since 1985, the period for the onset of the devastating famine of the 1980s, there had not been that much fluctuation in the aid flow from the bilateral donors, both for the total and average aid flow during the study period. The exception was that there was a jump in aid flow from bilateral donors in 2003 . The surge in aid inflow for 2003 could possible be in the form of emergency aid and food aid to respond to the 2002 drought. In 2002, there was shortage of rain during the two harvest seasons - the Belg and the Mehr, which arrive around February and June, respectively - withered over 70 percent of the maize and sorghum

\footnotetext{
${ }^{3}$ Graph for the bilateral aid flow overtime is not presented in the paper to save space. Interested readers may request from the author.
} 
crops, decimating grain production. During the same year, Ethiopia produced 25 percent less cereals and pulses than the previous year (FAO, 2003).

Figure 1: Average Aid Inflows by Year: 1960-2003

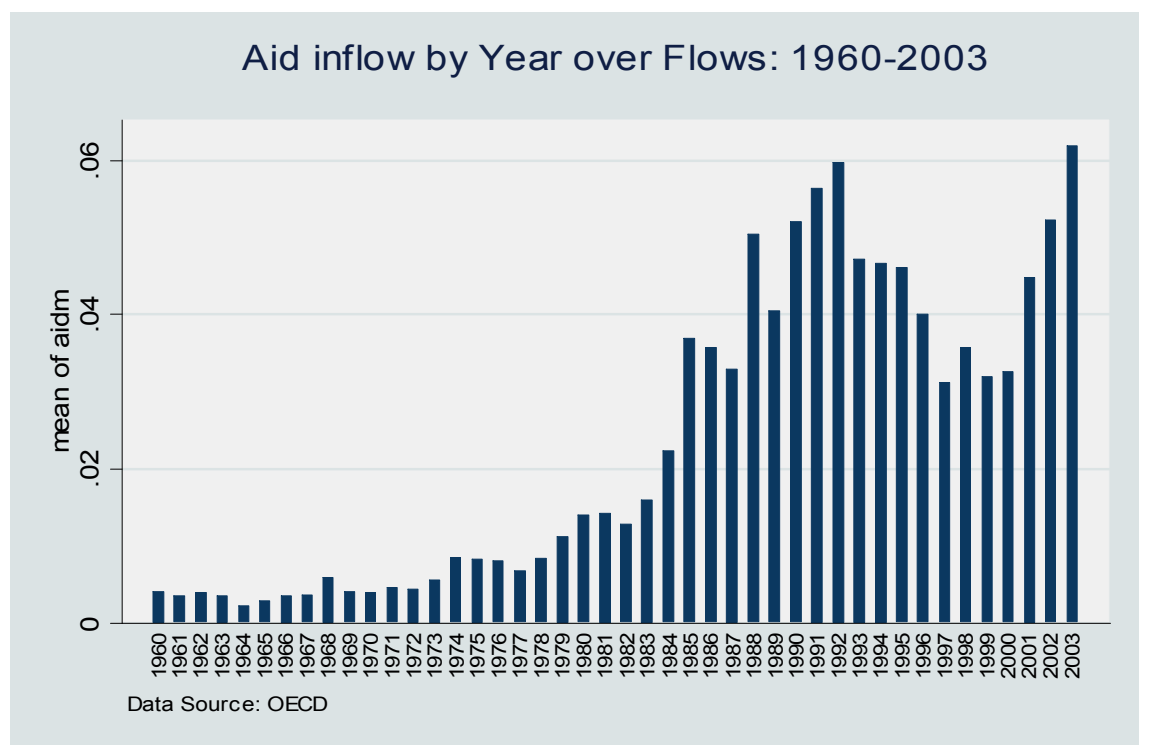

The country has been receiving aid in various forms ranging from technical assistance to food aid (Figure 2). Note that type of aid flow list all forms of capital inflows including market based capital flows to the private sector. In the figure below, portfolio and FDI flows refer to flows to the private sector; it should not be considered as aid to the private sector. During the period from 1960 to 2003, Ethiopia received more aid flows in the form of ODA (Official Development Assistance) grant followed by ODA loan. Aid in the form of technical cooperation and food aid took the third and the fourth places, respectively. The remaining aid flows were directed to the private sector. Taking the average flows, the same ranking can be observed, except that flows in the form of technical cooperation dropped below flows to the private sector (including export credits and contractual lending) and food aid (Figure 2). It can easily be seen that flows in the form of foreign direct investment and portfolio investment are at the bottom of the list for the period under consideration. This is not unexpected for Ethiopia, 
as the country's economy has not been performing that well to attract private capital and market based loans.

Figure 2: Average Aid Inflows by Type of Aid: 1960-2003

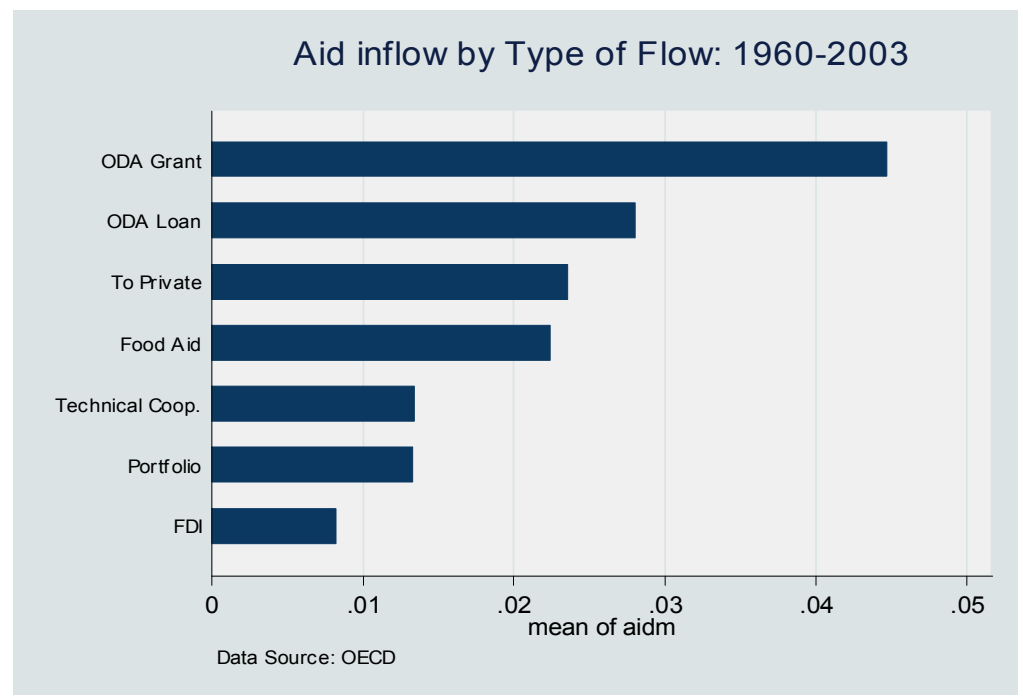

Figure 3 indicates major multilateral donors during the period 1960-2003. EU, followed by the World Bank and World Food Program, were the major multilateral donors. The other two multilateral agencies were Africa (African Development Bank and African Development Fund) and World Food Program (Figure 3). Similar pattern can be observed if one takes either the average aid or the total aid flow over donors during the period 1960-2003. Given frequent droughts followed by famine, the importance of aid from World Food Program is not surprising for the case of Ethiopia. It is also important to note that 15 of the $22 \mathrm{DAC}$ member countries belong to EU and they share as a group is expected to be high. It provides the sum of individual EU member countries. 
Figure 3: Average Inflows by Multilateral Donors: 1960-2003

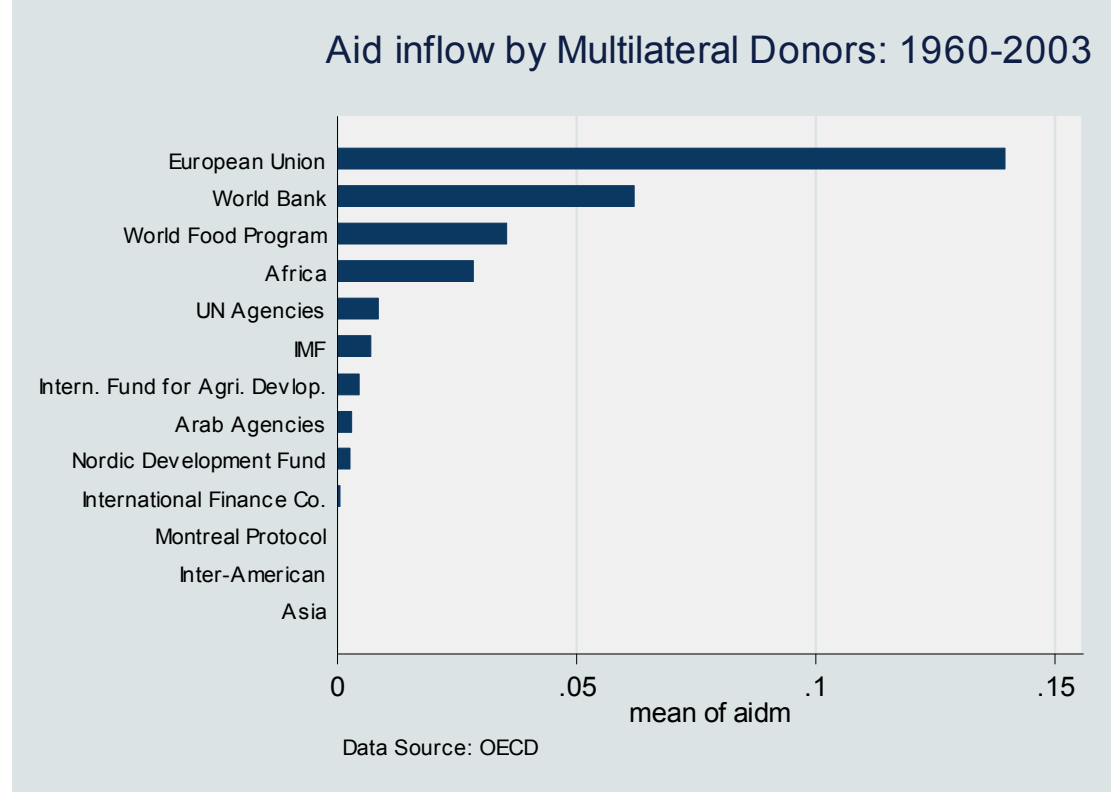

Among the bilateral donors, U.S., Italy, Germany, Sweden, and the Netherlands took the top position in that order during the study period. This is true for both the total aid flow and the average aid flow (Figure 4). The role of Italy is obvious given the historical ties of the two countries, especially until Eritrea split from Ethiopia in 1993. The role of U.S in supporting Ethiopia was significant during the 1960s and early 1970s until the Derg had taken power from the imperial regime. Recently, the relationship between U.S and Ethiopia seem to be more than ever for various reasons (more on this later). The humanitarian and development contributions of other European countries, including German, Sweden and, to some extent, the Netherland, are easy to notice in Ethiopia, especially their support for local governmental and nongovernmental organizations and for infrastructure development.

Having identified the major forms of flow, the major donors and the overall trend of aid flow into Ethiopia during 1960-2003, now let us turn to the details of the flow, particularly who has been giving in what form and during which regime. 
Figure 4: Average Aid Inflow by Bilateral Donors: 1960-2003

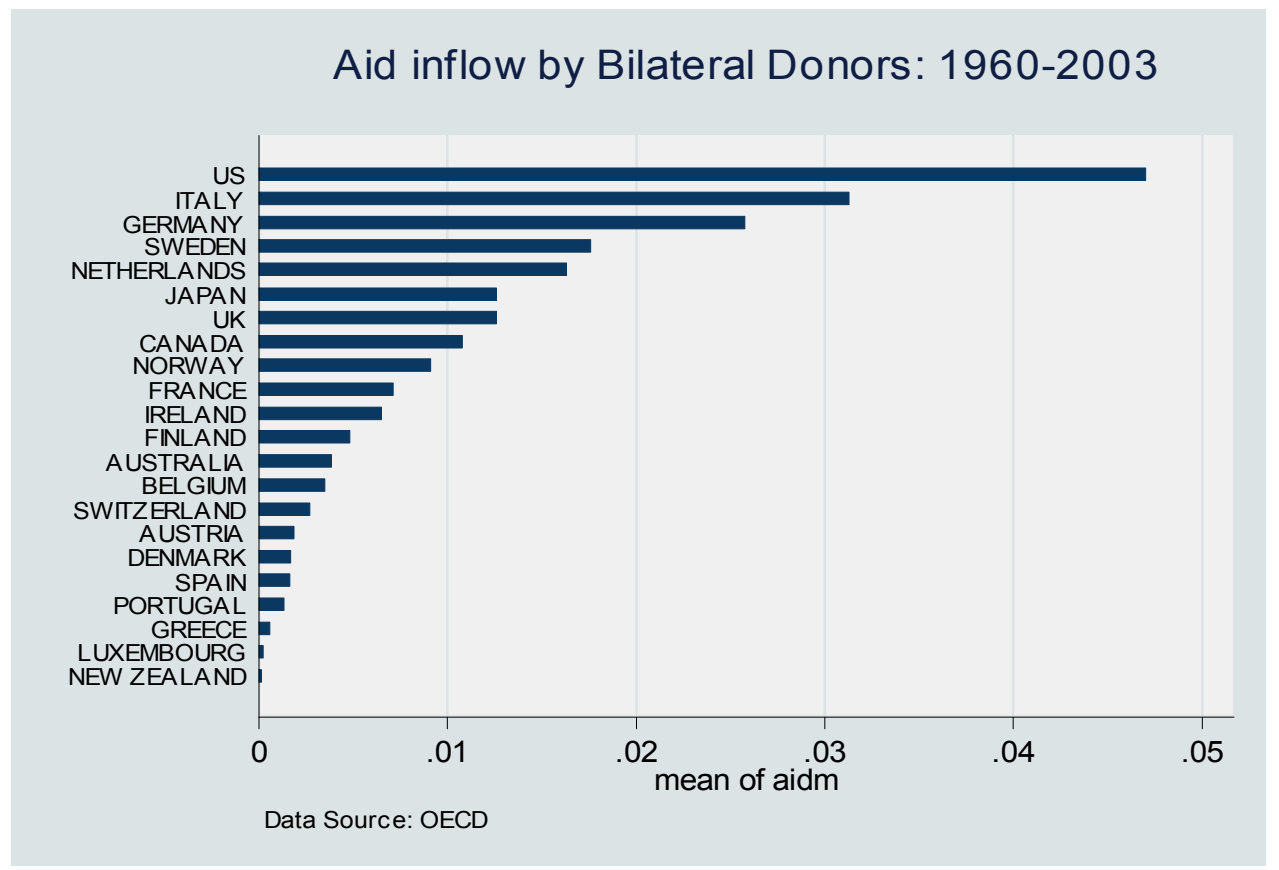

\section{Who was giving when and what?}

\section{Aid inflows by Regime}

Regime here refers to the different governments who came to power by involuntarily overthrow of governments that preceding each regime. In the case of Ethiopia, three regimes can be observed based on the availability of data from 1960-2003. The three regimes are Imperial regime (1960-1973), Military (Derg) regime (1974-1990) and the current regime (1991-2003). It is important to note that Eritrea was part of Ethiopia until 1993; hence, the data have not been adjusted for that at least until 1990. This may overestimate the aid flow to Ethiopia, this is especially true for the first two regimes, as some commentators claim, since significant share of the aid money have been invested or spent on Eritrea to appease the then guerilla fighters and the current leaders of Eritrea. 
As one can expect, the imperial regime received the least total (and average) aid flows compared to the other two regimes. At least two reasons account for this. Internationally, pre1970 was the period when cold war was not the major factor for countries to help others through aid to attract them to their camp. The second reason for the invisible flow of aid to the country was due to the decision by the regime of Ethiopia at that time to hide from international media attention the drought and famine that had swept the northern part of the country.

Figure 5: Average Aid Inflows by Types of Flow over Regimes

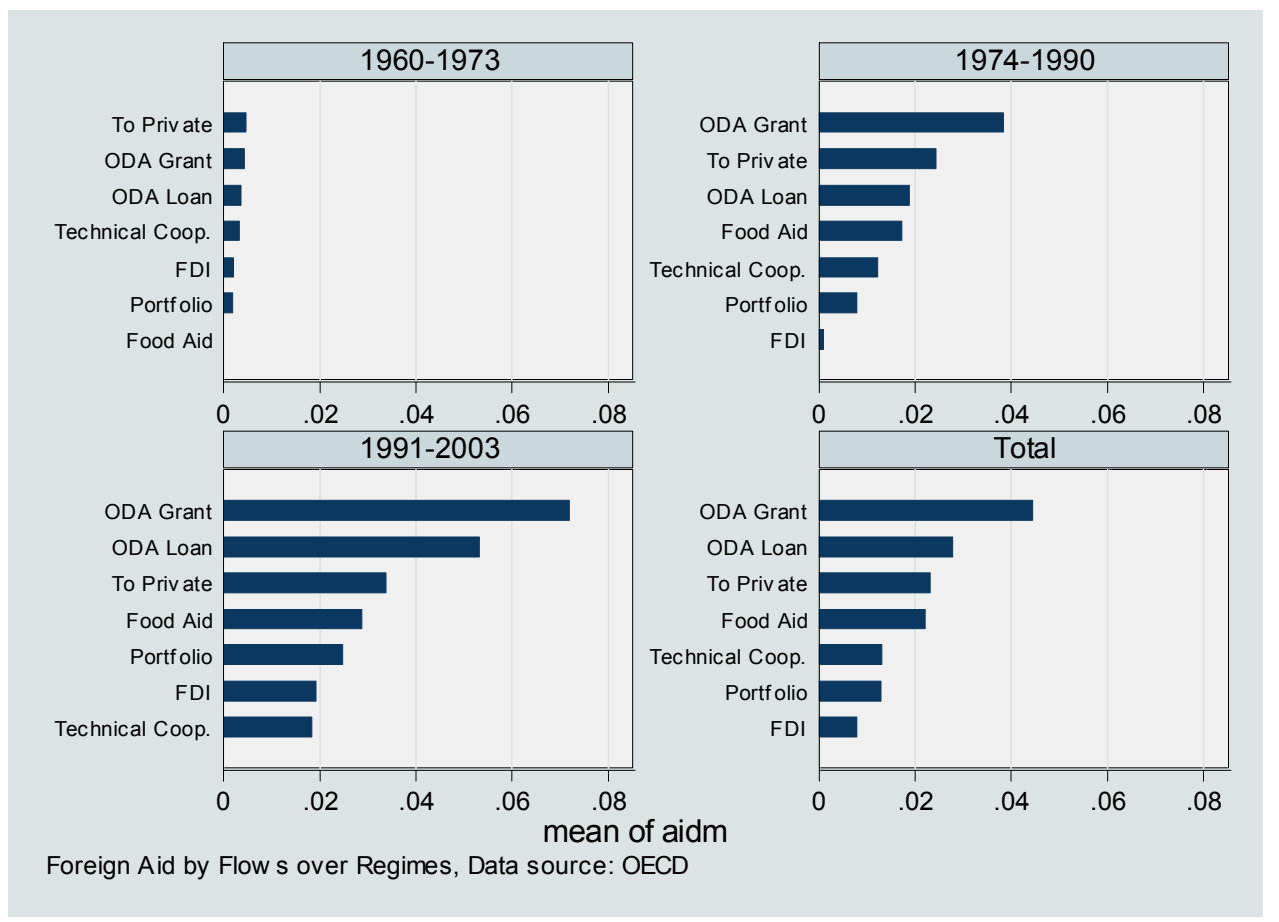

Hence, although food aid accounts for significant share during the last two regimes, it was at the bottom during the imperial regime (Figure 5). For the last two regimes, average aid money 
in the form of ODA grant tops the list. For the first regime, capital flow to the private sector came first. In terms of total aid money ${ }^{4}$, Aid in the form of technical cooperation ranks second for the first two regimes where as ODA loan was second for the current regime. Given the current government's willingness to adopt reform policies in line with the Washington consensus, aid money in the form of loan is easily forthcoming. As stated above, for the last two regimes, aid in the form of food aid takes the fourth place where as aid flows to private sectors were at the bottom of the list for the last two regimes. There are some differences between the average and the total aid flow during the period under consideration. One of the surprises is that aid money that went to the private sector (contractual lending and export credits) jumped to the top of the list for the imperial regime, and came second in the list (following ODA grant) during the military regime where as it came third for the current regime following ODA grant and ODA loan (Figure 5). It is surprising to the see aid money for the private sector during the military regime, which is a staunch supporter of command economy that advocates for the state control of the economic machinery.

In terms of major multilateral donors during each regime, EU, UN agencies, the World Bank, World Food Program, and African Development Bank/Fund top the list irrespective of regime change. EU was at the top of the list in terms of total aid flow followed by UN agencies and the World Bank for the first two regimes where as for the current regime World Bank comes second. Similar pattern can be observed for the average aid flow, except that for all the three regimes the World Bank came closer to the top of the list (Figure 6). If history is any guide, looking at the average aid inflow, the aid money that is coming through the World Bank and

\footnotetext{
${ }^{4}$ Graph for the total aid flow is not presented in the paper to save space.
} 
the private sector seem to be predictable and consistent throughout the period of study (more on this in the later sections).

Figure 6: Average Aid Inflows by Multilateral Donors over Regimes

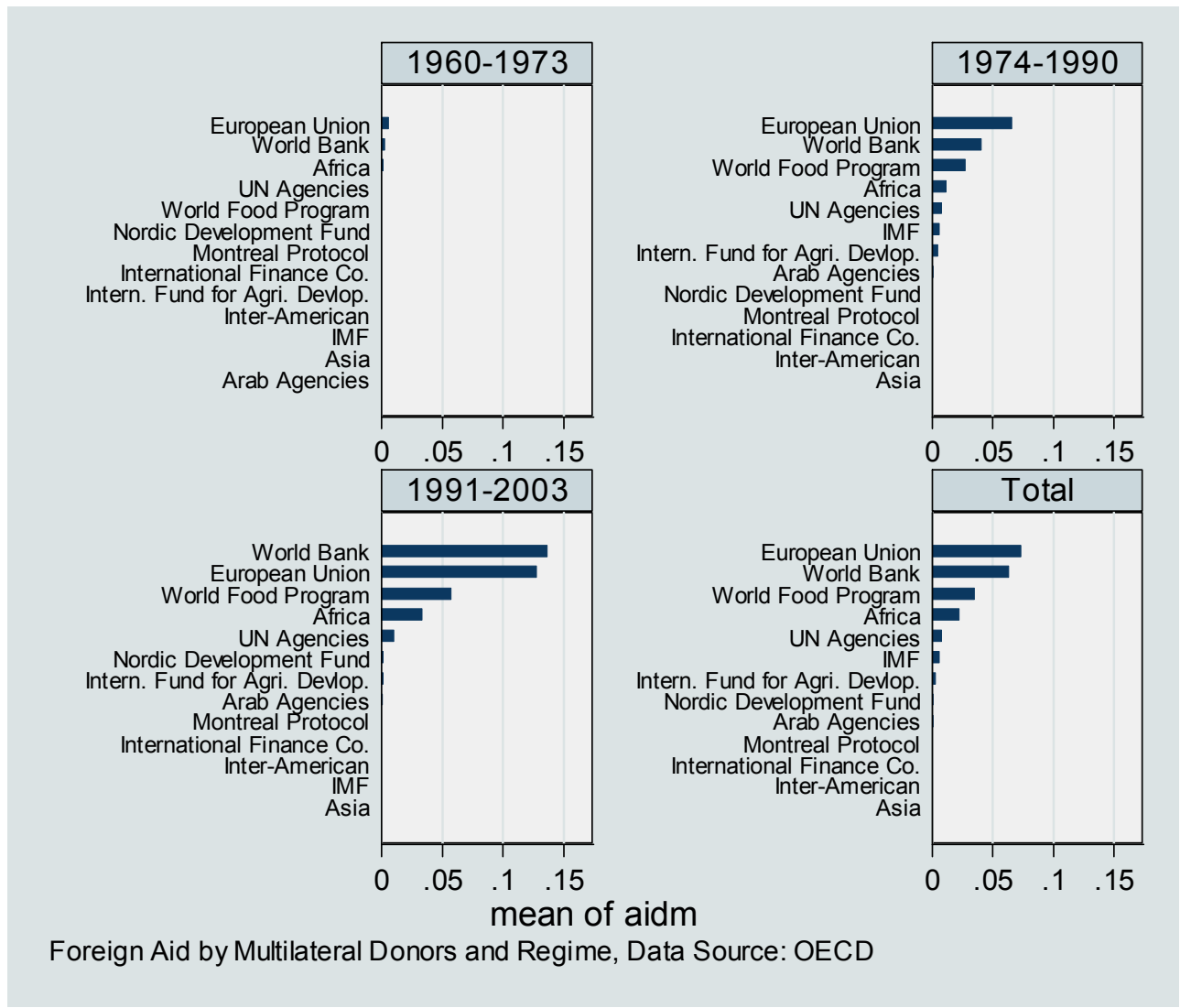

Regarding bilateral donors, as indicated in the previous section, five countries still top the list of bilateral donors during the three regimes of Ethiopia. These countries are U.S, Sweden, Germany, Italy, and the Netherlands. Looking at the bilateral donors in each regime, the role that U.K, Japan, and Canada play becomes noticeable. While still U.S. holds the top position as a major bilateral donor during the first and the last regimes, Italy took the top rank for the its aid money flow during the military regime. One needs to consider the role of Eritrea when looking at the contributions of Italy. The military regime - the period when Italy tops the list- 
is the period when Eritrea was part of Ethiopia, and Italy seems to have interest in the country as its citizens and economic interests were at stake at that time. During the current regime, the aid money coming from Italy dropped down to sixth place in the list (Figure 7). Sweden follows U.S. in its average aid flows to Ethiopia during the imperial regime. The country was at third place, following Italy and U.S., during the military regime, whereas its average aid placed Sweden even below Japan at the fifth place during 1991-2003. One of the features of aid money from Sweden (and for that matter for most Scandinavian countries) is that the country often give aid for humanitarian purposes and during the first two regimes when aid money was not forthcoming from other sources, Sweden was providing aid under both regimes. Canada and U.K. surpassed the Netherlands in terms of the average aid flow to the country during the military regime (for the case of Canada) and during the first two regimes for the case of U.K. For the current regime, Japan took the fourth spot surpassing Sweden and Italy, which had been in the top four for the past two regimes.

For the current regime, the good news is that other bilateral donors have been entering the list and made significant contributions in terms of average aid inflow, at least compared to the imperial regime. These countries are Norway, Canada, Ireland, France, Finland, Belgium, Switzerland, Australia, Denmark, and Austria. It is good news not just for the current regime but also for the country as a whole since the list is dominated by Scandinavian countries whose aid often times destined for humanitarian purposes rather than to achieve donor country national interests, as it is alleged for the other western donor countries. 
Figure 7: Average Aid Inflows by Bilateral Donors over Regimes

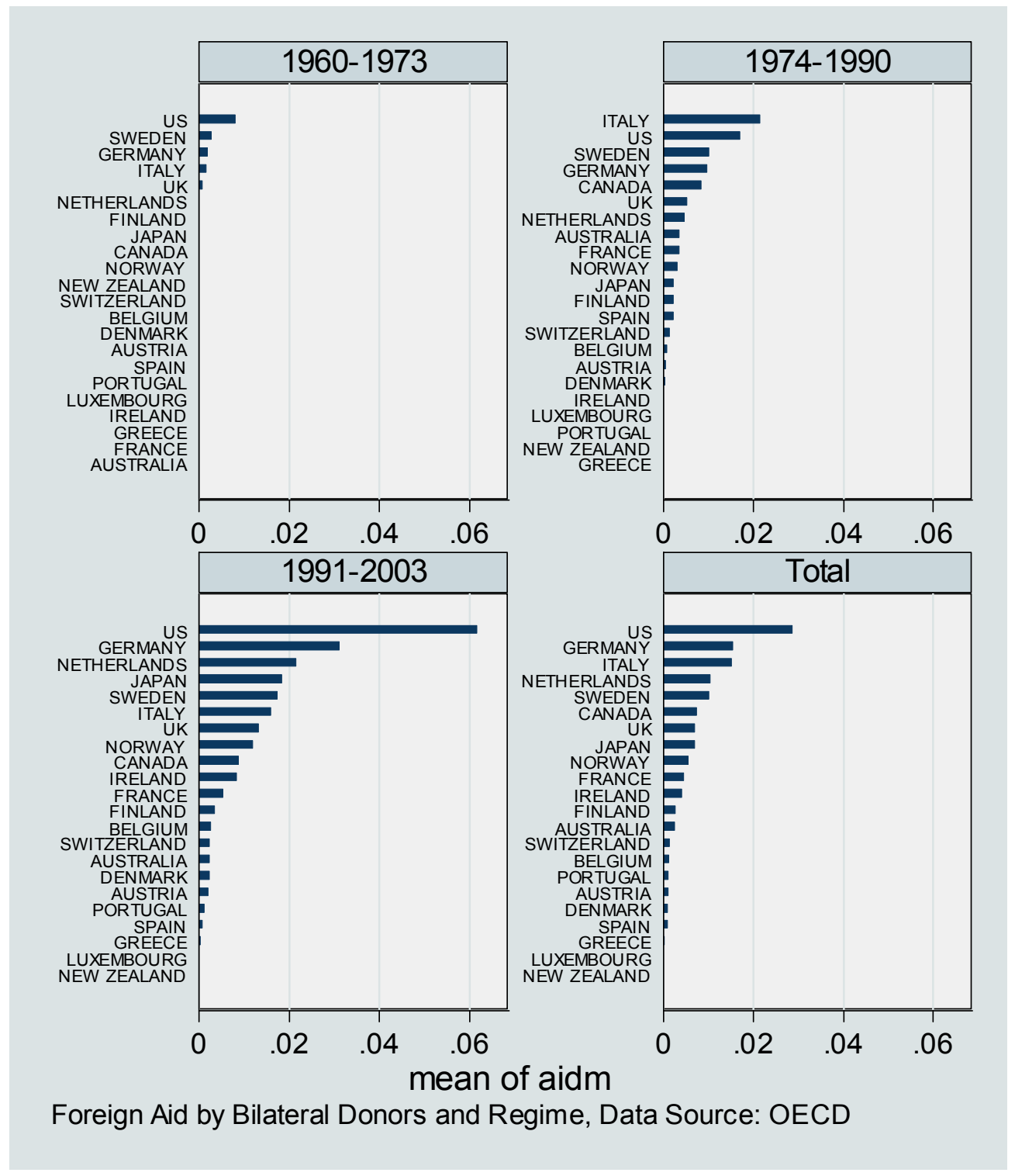

\section{Who was giving in what form?}

In previous sections, it has been noted that the major bilateral donors and the different forms in which the country has been receiving aid. Now let us see the break down of forms by which the aid money has been coming and which countries gave in what form. The focus is on those 
major donors (U.S., Canada, Japan, Italy, Germany, the Netherlands, Sweden, and U.K.) and the recent additions to the list especially after the overthrow of the military regime (Norway, Australia, France, and Ireland). Almost all major donors gave aid in the form of ODA grant as their major means. It is no a surprise that for the major crop producing countries like Canada, U.K., Norway, and U.S (countries that support their agricultural sector); food aid was their next best means to hand in aid. Cline indicates that during the period 2000-2002, on average, output-distorting subsidies as percent of agricultural output were $19.9 \%$ for U.S., $1.65 \%$ for Canada, and 36.2\% for European Union (Cline, 2004). It is important to note that food aid, as it is presented here, does not include emergency and relief food delivered during the times of distress in the country. The food aid listed here is categorized as aid under program assistance. If one adds food aid under program assistance and that listed under emergency and relief, the proportion would have been much higher for these countries.

Aid in the form of technical cooperation comes next to ODA grant for Sweden, Japan, the Netherlands, Germany, and France. For the other major donors, aid in the form of technical assistance ranks third following grant and food aid. The world's biggest economies - U.S, Germany, and Japan- also gave significant amount of development loans to Ethiopia (Figure 8). It seems that, for most of the countries, during the study period aid came in kind - food aid and technical cooperation- than in cash. Aid in kind comes with its shortcomings. First, the aid may help particular sector, which may not be the priority of the country, probably the country might want to have cash to buy food from surplus producing regions of the country rather than receiving food in kind. The same issue can be raised for the case of technical cooperation, for instance in the form of training, which may help sectors that may not be at the priority of the 
countries development agenda. Second, it is also the case that aid received in kind may end up being sold in back-door markets and the proceeds may be embezzled by officials. The same problem can also be raised for the case of aid in cash; however, in the case of food aid the targeted recipients live in remote places, and it is difficult to track down whether they have actually received the food intended for them and how that affects the rural economy. For instance, see Zhang, 2004 for the likely effects of food aid on the local and international food markets. Technical cooperation seems better in this regard since the purpose is to increase the skill (human capital) level and the physical capital stock in the country, which can be easily verifiable. 
Figure 8: Average Aid Inflows Type of Flows over Bilateral Donors

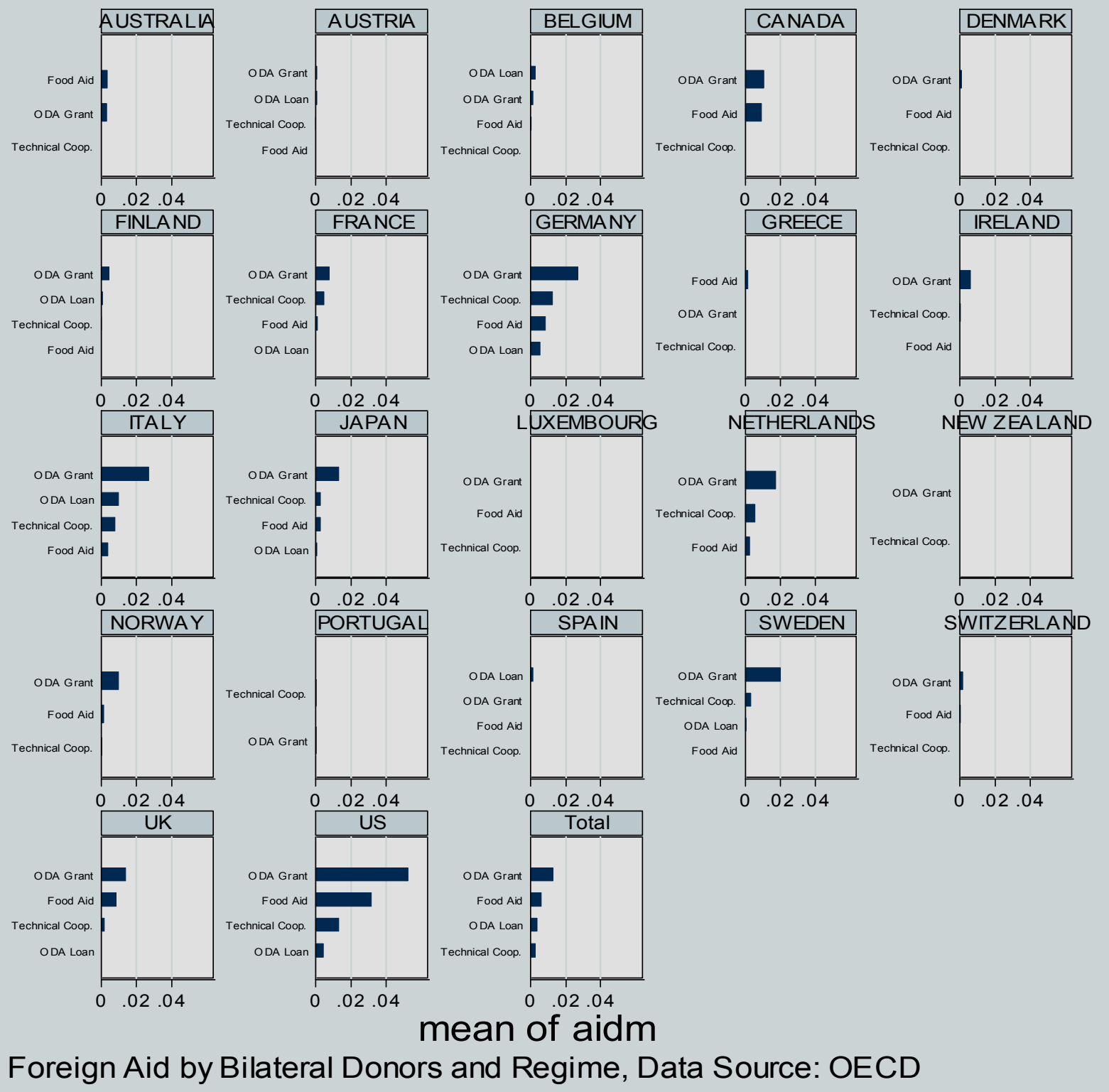

Predictability and sustainability of aid flow is crucial for countries like Ethiopia that are dependent on aid to finance deficits, to emergency relief, and to build infrastructure. To get the feel of predictability and sustainability, smoothed trends of aid flow over time for each donor (bilateral and multilateral) is presented below in Figures 9, 10, and 11. 
Lowess, local regression smoothing, is used to the present smoothed trends in the flows of aid by bilateral donors (Figure 9), multilateral donors (Figure 10), and forms/types of flow (Figure 11). The smoothed trends show how the respective donors change their aid flow overtime. Most bilateral donors' aid flow is almost flat during 1960-2003 except for U.S, Ireland, Germany, Italy, Japan, Netherland, and Sweden. Continuous increase in aid flow is observed for U.S, Ireland, Netherlands, and, to some extent, Japan. While others, like Italy, Germany, and Sweden registered a downward trend in recent years; U.S, Ireland, U.K, the Netherlands, and Japan, had an upward trend during the early 2000s. As indicated in the overall trend for all countries, the recent decline in the aid flow has to do with the recent border conflict and war between Ethiopia and Eritrea. For the later countries, mainly U.S., the Netherlands, and U.K, that did not deter them from sending more aid to Ethiopia. Aid inflows from multilateral donors were also flat except for the flows from the World Bank, African Development Bank/Fund, World Food Program, and EU (Figure 10). The flows from the World Bank echoes that of the U.S with its continuous flow even for recent years. For the other donors, Africa, EU and World Food Program, the aid flow picked in early 1990s then slid back to its historic average during recent years echoing the trends of some European countries including Italy, Germany and Sweden. From the above two smoothed trends predictability is not forthcoming for all countries. It is not that all countries increase or decrease their aid flow at one time. Some donors increase during one period, while other increase during other periods. Does this imply national interest of donors not the socio-economic milieu of the country? It can also be due to division of labor among donors, where some donors give only for humanitarian needs at times of crisis while others give for projects and for long-term development programs (EU and the World Bank). Predictability of the later is important, nevertheless, even for the major donors, 
like EU, sustainability seem not something that the country can count on as one can see from the decline in aid flow from EU in recent years.

Figure 9: Lowess Smoothing of Average Aid Inflows over Type of Flows: 1960-1003

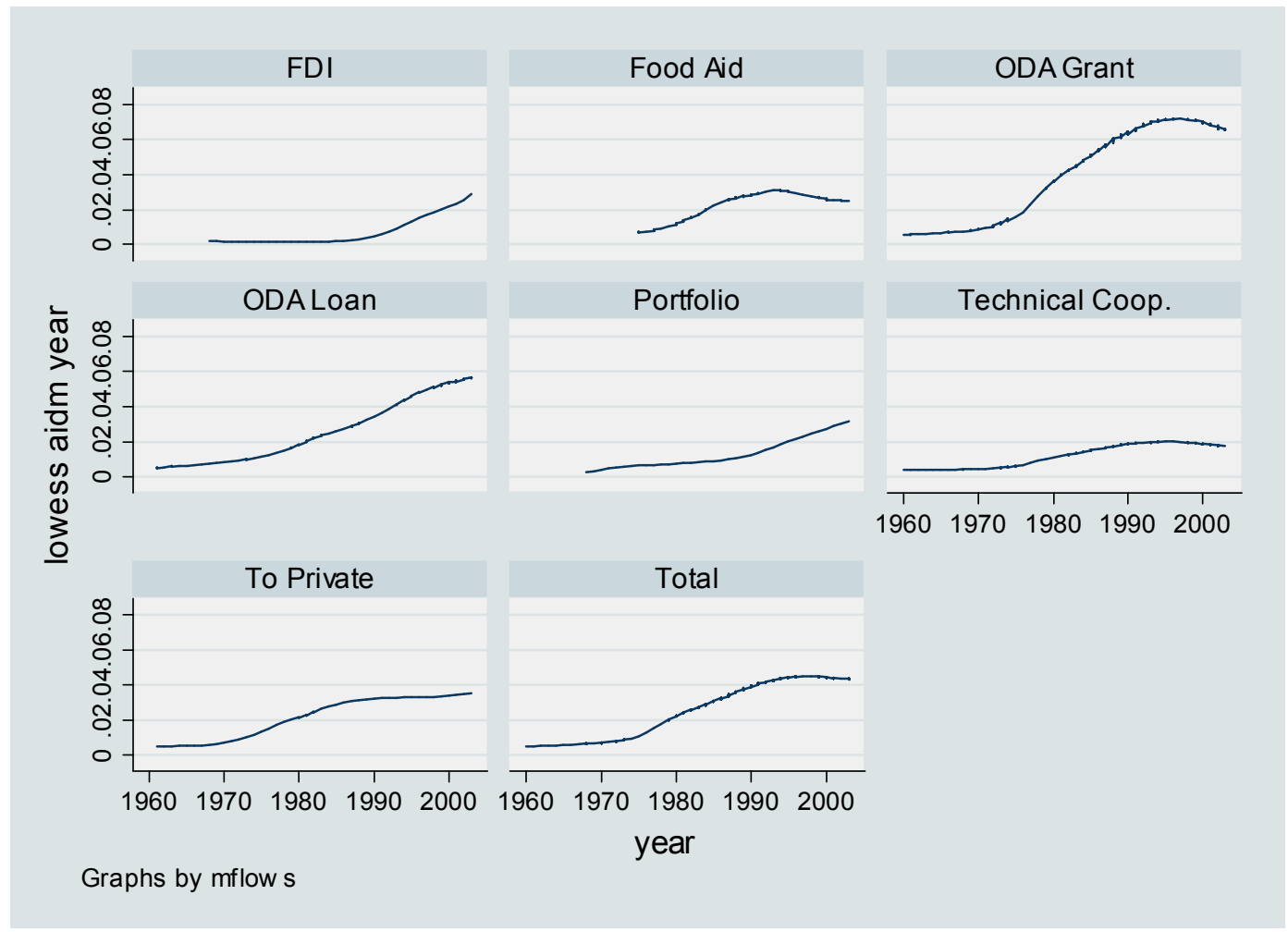


Figure 10: Lowess Smoothing of Average Aid Inflows over Bilateral Donors: 1960-2003

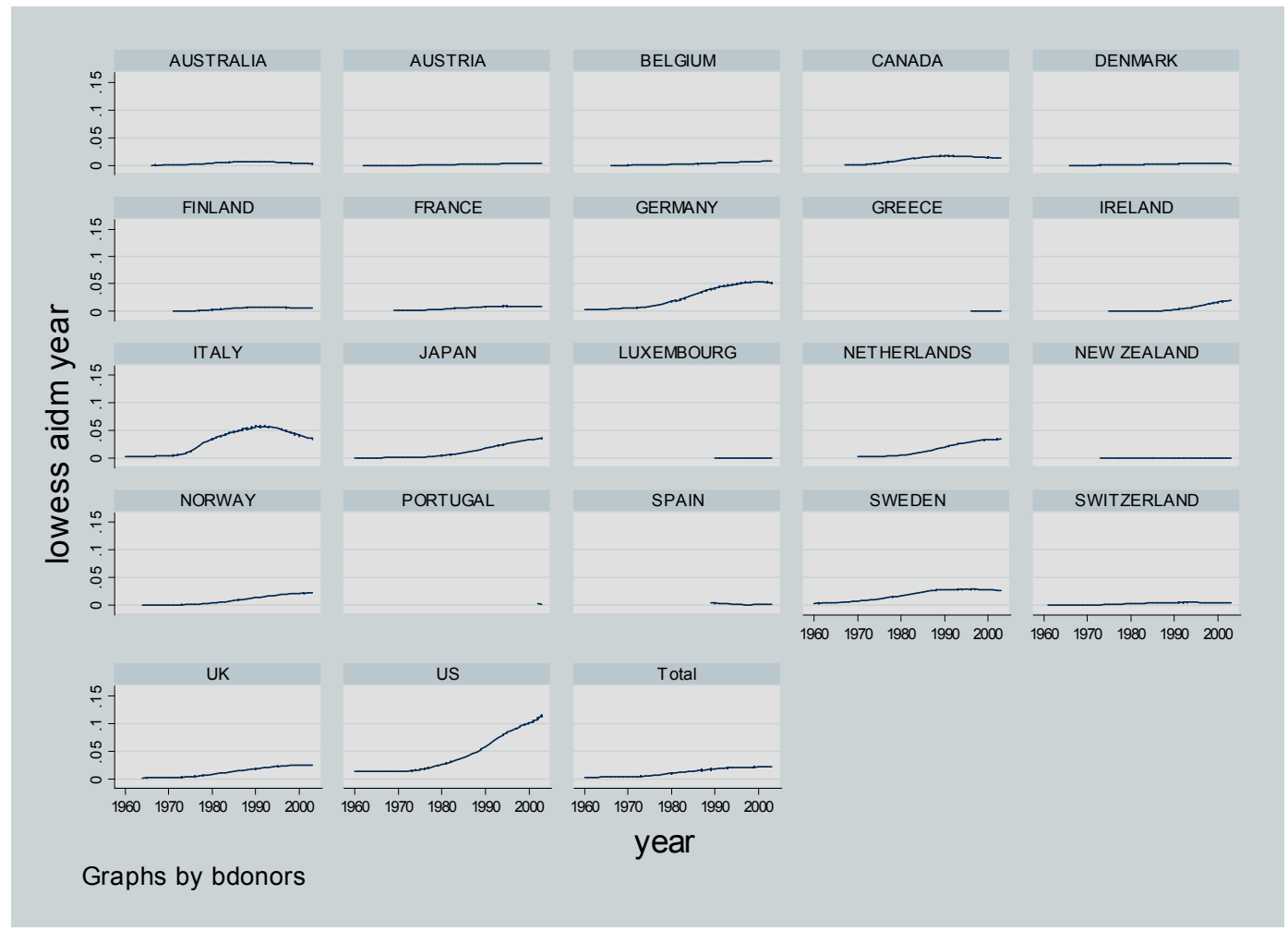

There is something to rejoice though, all the major forms/types of capital inflows show increasing trend, especially in recent years. Flows to the private sector (FDI, Portfolio, and other private) and in the form of Official Development Assistances (both grants and loans) were pouring in at increasing rate in recent years. The other major forms of aid flow - Food Aid and Technical Cooperation- registered an increased flow although at a decreasing rate (Figure 11). This looks a healthy sign for emerging economy where official aid flows are replaced by private capital flows. However, for a country like Ethiopia where the capital market is not well developed (or none existent) and where the effect of the aid flow has been just started to be felt in most rural parts of the country, it is too early to expect the role of private capital flows to play significant role in the country. It may be unhealthy if the rate of infrastructure development lags behind that of the private capital flow. It is important to note 
here that the private capital flows are just a recent phenomenon. If one can check back Figure 2 that presents average aid flow by type of flow, compared to other forms of capital flow, flows to the private sector are at the bottom of the list. This seems an expected outcome where flow of money to the private sector is waiting for the effect of development grants and loans to be felt across the interlinked sectors of the economy.

Figure 11: Lowess smoothing of Average Aid Inflows over Multilateral Donors: 1960-2003

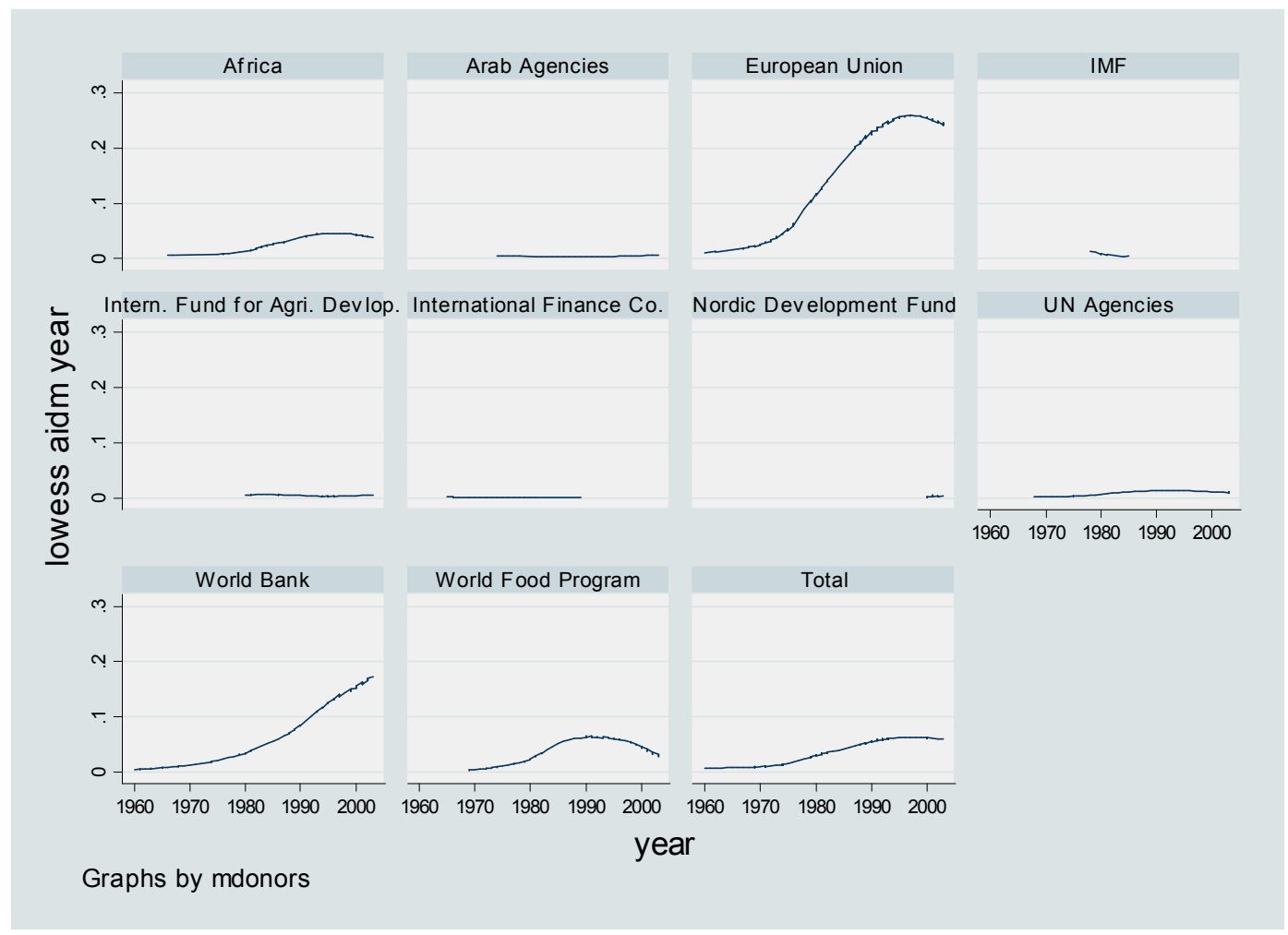

\section{Distribution of Aid by Sector/Purpose: 1973-2003}

The OECD dataset also compiled information on aid flow by purpose or sectoral distribution. Since the data reported for each donor and for each year are not complete, only average aid flows are used for discussion purposes in this part of the study. The major sectors/purposes used in the OECD dataset are described in the Appendix. The sectors are social infrastructure 
and services, economic infrastructure and services, production sectors, emergency assistance, help with debt, multi-sector, program assistance, and unallocated/unspecified. According to the definition of OECD, these sectors can be grouped into two: aid for (direct) production activities (including infrastructure and services) and aid for non-productive (including emergency assistances). Productive activities include allocation of aid to social and economic infrastructure and service, production sectors, and multi-sectors. Non-productive activities include aid flows to program assistances as well as emergency assistances, which mainly refer to food aid, and help with aid. As one can see from figure 12, during the period 1973-2003, large sum of aid money went to the non-productive activities, mainly program and emergency assistances and help with aid. The exception is that the fund that was destined for social infrastructure and services was in the middle of the top lists. On average basis, considering all donors, aid allocations to almost all directly productive sectors were at the bottom of the list.

It is worthy of the time and space to talk more about one of the non-productive purposes for which the country received during this period: Help with debt. It seems that help with the debt initiatives got much publicity after the 1996 HIPC (Highly Indebted Poor Countries) initiative by the World Bank and IMF; later followed by similar initiative after the Gleneagles summit in July 2005. The objective of both initiatives is to cancel all or most of the debt owed by poor countries of the world. Ethiopia has been benefiting from both initiatives, but what is relevant for the period study is the HIPC initiatives. The initiative sounds and looks convincing and altruistic from donors and recipients point of view in that it relieves poor countries from debt services that they could not manage to pay now. Developing countries scholars and commentators, however, immediately raised question regarding the initiatives. One concern 
that keeps coming is that debt relief may end up being a substitute for additional aid. Donors who consider debt cancellation may not plan to extend fresh grants or loans, but poor countries, despite accumulated debt, still needs more grants and/or loans to finance their deficits or development projects (Arslanalp and Henry, 2006; Rogoff, 2005). Hence, it may be to early to count on the debt relief component of aid unless fresh aid money keeps coming at a sustainable rate and magnitude.

Figure 12: Average Aid Inflows by Sectors: 1973-2003

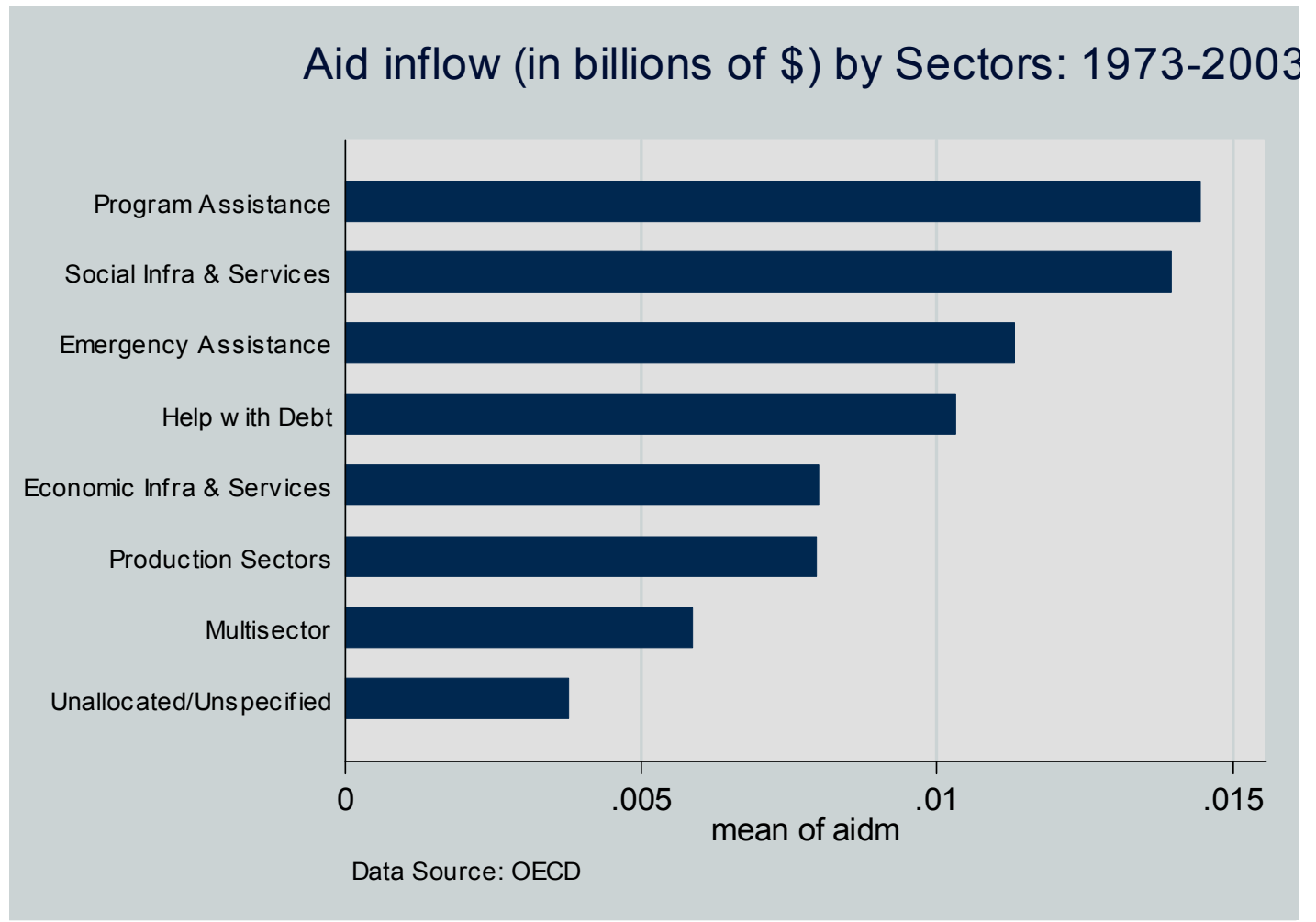

\section{Sectoral Distribution of Aid by Regime}

Only the last two regimes are considered for the sectoral distribution aid money since the data starts in 1973. The sectoral distribution of aid money for the current regime echoes that of the 
total allocation in that aid money mainly went to non-productive activities with the exception of aid for the social infrastructure and service sector. It is surprising to see that the military regime received more money for productive sector than the current regime, despite the buzz about the extensive infrastructure development during the current regime. One can argue that although the aid statistics shows that the country had received aid money for productive activities during the military regime, some of that money might have been diverted to other non-productive sector and resulted in the debt burden. It is also important to note that during both regimes, program assistance was one of the main aid recipient sectors, which mainly was in the form of food aid (Figure 13).

Figure 13: Average Aid Inflows by Sectors over Regimes

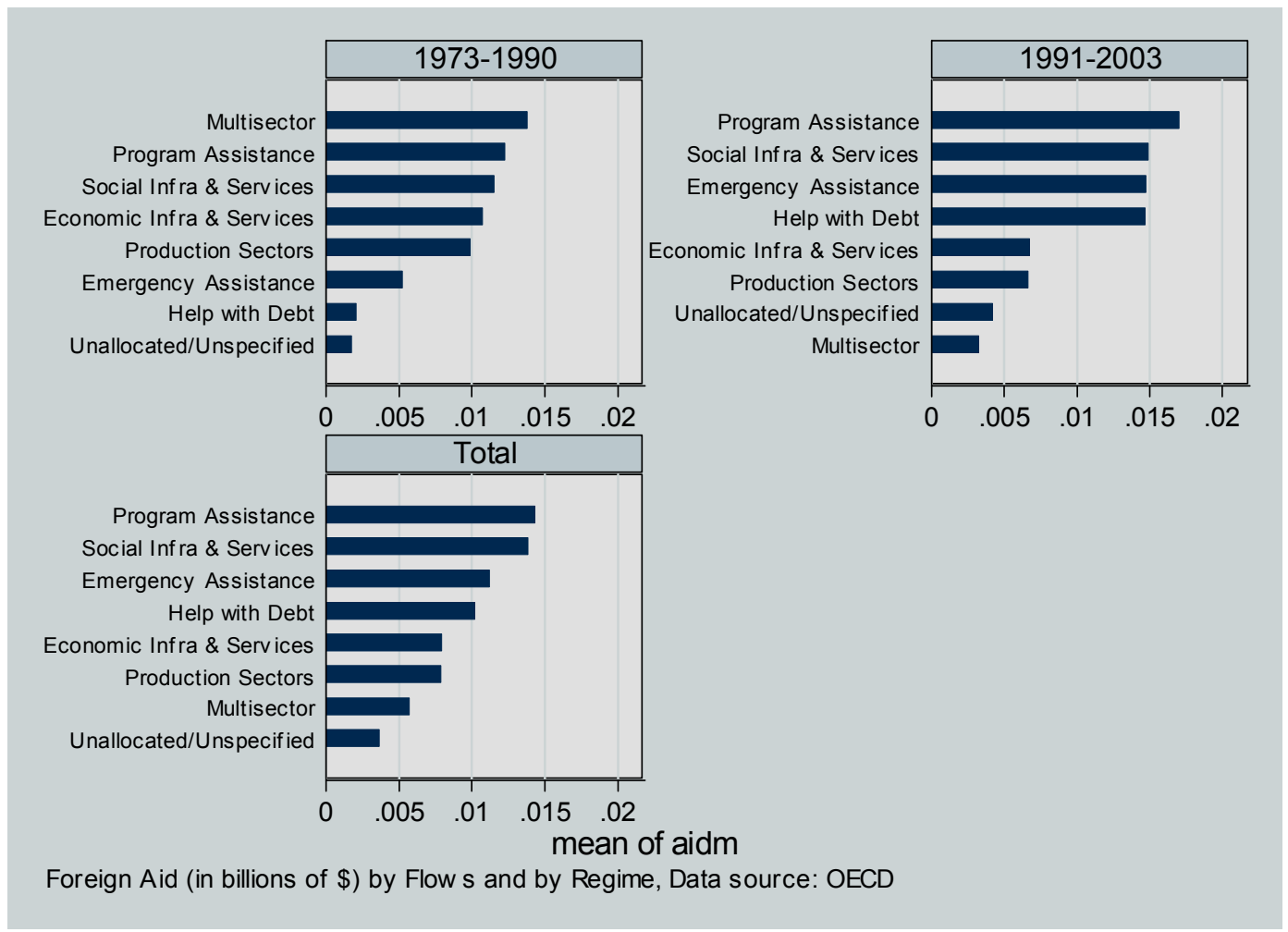




\section{Sectoral Distribution of Aid inflow by Bilateral Donors}

Which donors gave for productive sectors and which ones gave for non-productive activities?

The draft description here echoes that of the preceding discussion where countries ranked by the type/method of aid (Figure 8). Figure 14 illustrates rank of donor countries under each sector. Countries that top the rank of aid flow to the emergency and program assistance are those listed as major food aid donors including the U.S, U.K, Norway, Canada, Germany, Sweden, and Japan. When it comes to emergency assistance, U.S and UK are at the top as they have the largest Ethiopian diaspora living in their country, and it is politically correct for the world powers to respond to emergency needs. Italy and Germany, in addition to their aid money that went to help with debt, also rank at the top for their aid flows to the production sector and economic infrastructure and services (following Japan). Flow of aid to the social infrastructure and services sector is toped by U.S followed by Germany, Sweden, and Ireland. The figure further shows that, in terms of magnitude, Ethiopia received more aid money for emergency assistance from U.S than any other country and to any other sector during the three decades. Following that aid money went to help with debt and to program assistance, all of which, except perhaps program assistance, are not directly productive sectors. 
Figure 14: Average Aid Inflows by Bilateral Donors over Sectors: 1973-2003

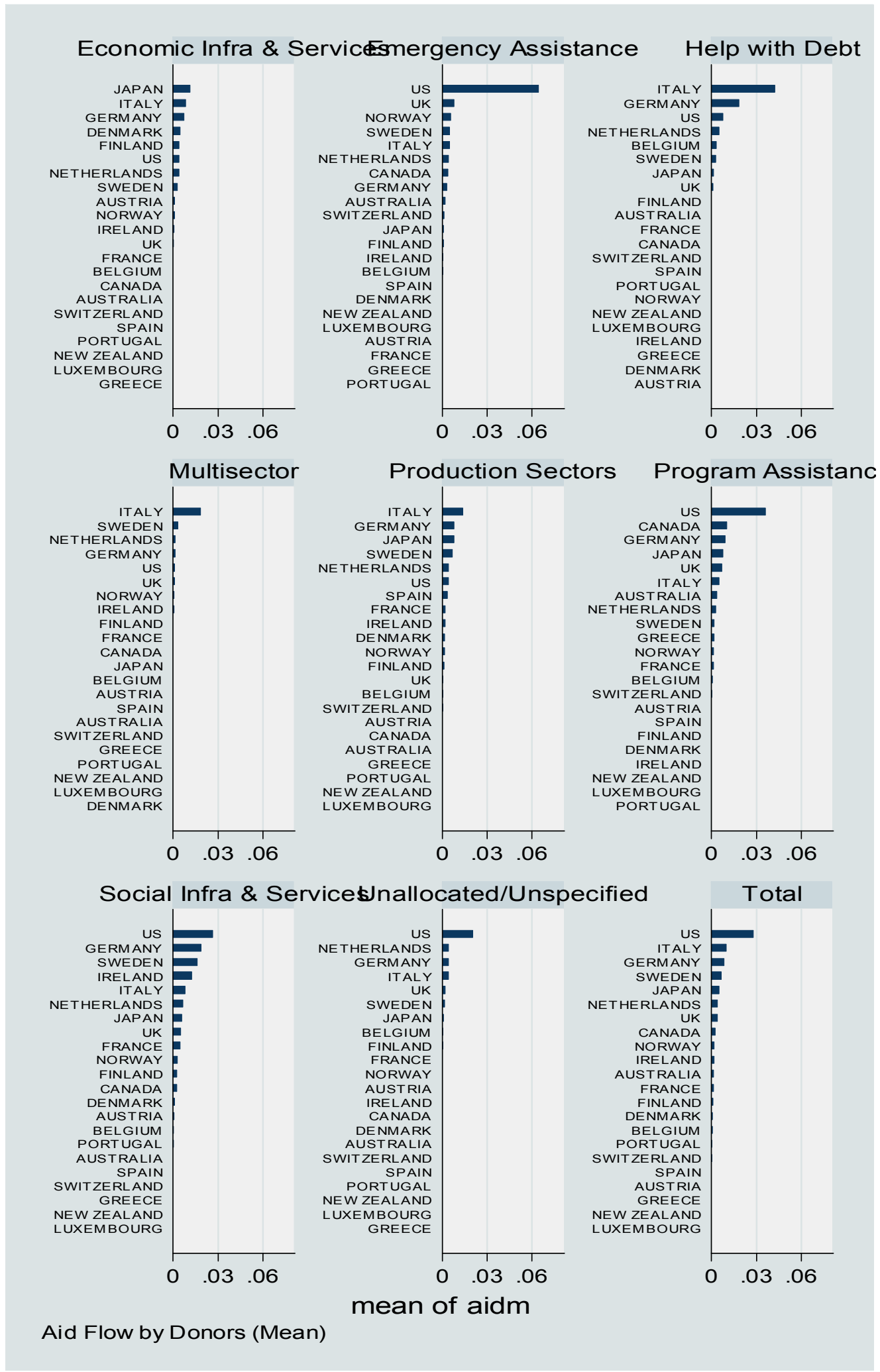


The overall trend of aid flow to the major sectors is reported in Figure 15. The figure presents local regression smoothing trend during the last three decades. Aid flows to two of the productive sectors (economic infrastructure, and production) have been flat. Flows to the social infrastructure and multi-sector activities registered modest increases in recent years. Significant jumps in aid flow have been recorded for emergency assistance. Aid flows to program assistance has also jumped during early 1990s and remained stable since then. Help with debt has also jumped during late 1990s, however, it retuned to its historic average in recent years.

Figure 15: Lowess Smoothing of Average Aid Inflows over Sectors: 1973-2003

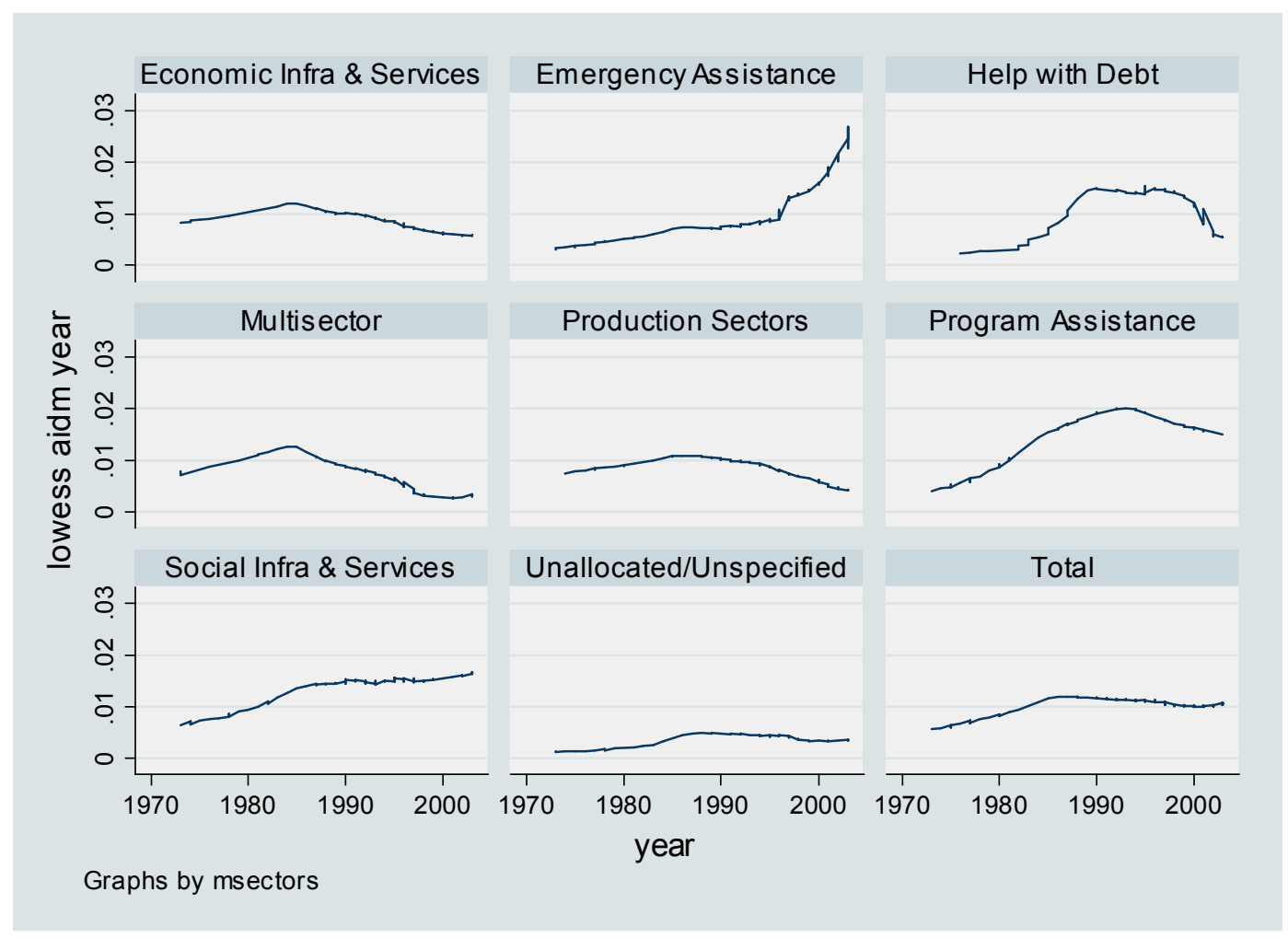




\section{Conclusions}

The main trust of this study is to present profile of aid inflow to Ethiopia. Attempt is made to document the aid inflow from bilateral and multilateral donors by type/method of flow during the past four decades (1960-2003) as well as aid flow from bilateral donors by purpose/sector during the last three decades (1973-2003). Geographic and Sectoral aid distribution data made available by OECD has been employed to document the profile. For each of these the aid flows variation by regime is also reported.

It is documented that major bilateral donor countries are U.S, Italy, Germany, Sweden, Netherlands, Japan, and UK. European Union, World Bank, World Food Program, and African Development Bank/Fund top the rank of major multilateral donors. Aid money came into the country mainly through Official Development Assistance (both in the form of grant and loan) followed by flows to the private sector (export credit and lending) and food aid, on average basis during 1960-2003. There is an upward trend in aid inflow in the form of foreign direct investment, portfolio, and flows through other private means. It is important to note that there were significant variations in aid flow across regimes in terms of the donors and the type/method that aid money have been delivered.

The major sectors that received the largest aid money during the last three regimes were program and emergency assistances (mainly food aid), social and infrastructure and services, and help with debt. There has also been significant variation across regimes and donors in terms of which sectors received the largest aid money. In recent years, emergency assistance and social infrastructure has been receiving aid at an increasing rate. Whereas other sectors, 
like economic infrastructure, production sector, and multi-sector have received aid at a declining rate. Perhaps it is normal to expect the inflow of private capital into the productive sectors by the time the effects of the flow of aid money to the social infrastructure development are being felt nationwide. 


\section{Reference}

Alemayehu Geda. 2003. The Historical Origins of African Debt Crisis. EASSRR, Vol. xix, no. 1.

Arslanalp, Serken and Peter Blair Henry. 2006. Policy Watch: Debt Relief, Journal of Economic Perspectives, vol. 20, no. 1, pp 207-220.

Berhanu Abegaz. 2001. Post-Socialist Reformers: Ethiopia, in Aid and Reform in Africa, World Bank Development Research Group.

Bulow, Jermy and Kenneth Rogoff. 2005. Grants versus Loans, American Economic Review, vol. 95, issue 2, pp 393-397

Burnside, Craig, David Dollar. 2000. Aid, Policies and Growth, the American Economic Review, vol. 90. no. 4, September, pp847-868.

Clements, benedict, Sanjeev Gupta, Alexander Pivovarsky, Erwin R. Tiongson. 2004. Foreign Aid: Grants versus Loans, Finance and Development, September.

Cline, William R. (2004). Trade Policy and Global Poverty, Center for Global Development, Institute for International Economics, Washington, DC.

FAO. 2003. Ethiopia: drought-hit farmers receive emergency aid Pre-famine conditions in pockets of the country, 10 June 2003, Rome/Addis Ababa

FAO. 2007. FAO Urges Food Aid Reform. FAO News Online publication, downloaded on January 24, 2007 at http://www.fao.org/newsroom

IMF. 2006. The Federal Democratic Republic of Ethiopia: Selected Issues and Statistical Appendix. IMF Country Report No. 06/122.

Maxwell, Simon. 1996. Does European Aid Work? An Ethiopian Case Study, IDS Working Paper 46.

McLaughlin, Abraham. 2004. How Ethiopia's Cooking-Oil Industry Got Burned by US Aid. Christian Science Monitor, January 6.

OECD. 2005. Creditor Reporting System Aid Activities: 1973-2003.

......2005. Geographic Distribution of Financial Flows to Aid Recipients: 1960-2003.

......2005. International Development Statistics, CD-ROM, 2005 Edition.

Rogoff, Keneth. 2005. Debt Relief an Empty, Backward Gesture, BusinessDay, June 22. 
Wiedemann, Erich. 2005. Addicted to Aid in Ethiopia, Global Policy Forum, Novermber 25

Yamano, Takashi, Harold Alderman, Luc Christiaensen. 2003. Child Growth, Shocks, and Food Aid in Rural Ethiopia, World Bank Policy Research Working Paper 3128.

Zhang, Ruosi. 2004. Food Security: Food Trade Regime and Food Aid Regime. Journal of International Economic Law 7(3), 565-584. 


\section{Appendix: Data}

\section{Economic Sectors reported in CRS aid data (taken from OECD International Development Statistics, CD-ROM 2005 Edition)}

Social Infrastructure and Services: This category covers efforts to develop the human resource potential and ameliorate living conditions in aid recipient countries. It includes, but not exhausted by, the following sectors.

Education

Health and Population

Water Supply, Sanitation and Sewerage (excludes irrigation systems for agriculture).

Economic Infrastructure and Services: This category covers assistance for networks, utilities, and services that facilitate economic activity. It includes, but not exhausted by, the following sectors.

Energy

Transportation and Communications

Production Sectors: This category covers contributions to all directly productive sectors. It comprises:

Agriculture, Fishing \& Forestry

Industry, Mining \& Construction

Trade \& Tourism

Multi-sector: support for projects, which straddle several sectors, with a concentration on the environment, gender projects and urban and rural development

Program Assistance: all general developmental contributions other than debt reorganization, made available with no pre-imposed sector allocation, e.g., balance of payments and budget support and funds made available for capital projects at the recipient's choice, but not subject to agreement by the donor. This item includes in particular, sector unallocated structural adjustment assistance. It Includes:

Food Aid: supplies of food under bilateral programs

Action Relating to Debt: debt forgiveness, rescheduling, refinancing, etc

Emergency Assistance: emergency and distress relief in cash or in kind. It includes

Relief food aid

Aid to refugees

Unallocated/Unspecified: aid that cannot be assigned to another part of aid flow, and in the case of project or sector assistance, commitments for which the sectoral destination had not been specified. Includes aid to

Non-governmental organizations

Administrative costs 


\section{Definition of the terms used in the data sets}

Grants: this heading covers transfers, in money or in kind, for which no repayment is required. It includes grants for technical co-operation, grant-like flows, i.e., loans extended by governments or official agencies in currencies of the donor countries but repayable in recipients' currencies and transfer of resources through sales of commodities for recipients' currencies, less local currency balances used by the donor for other than development purposes (for example, to defray the local costs of embassy operations).

The following are excluded: reparations and indemnification payments to private individuals, insurance and similar payments to residents of developing countries, and loans extended in and repayable in recipients' currencies.

Multilateral Agencies: the list of multilateral agencies for which data are shown separately in this report is given in the Introduction. To the extent possible, a distinction has been made between concessional and nonconcessional flows from multilateral agencies. Loan disbursements for which it was not possible to make this distinction on a transaction-by-transaction basis have been treated as non-concessional if made from "ordinary capital" resources and as concessional if made from a "soft window". Thus, for some agencies "total loans" are significantly larger than loans on concessional terms, and the volume of loans on concessional terms actually received by the borrowing country may not be accurately measured.

Official Development Assistance (ODA) is defined as those flows to developing countries and multilateral institutions provided by official agencies, including state and local governments, or by their executive agencies, each transaction of which meets the following tests:

i) it is administered with the promotion of the economic development and welfare of developing countries as its main objective; and

ii) it is concessional in character and conveys a grant element of at least 25 per cent.

ODA Loans: loans with maturities of over one year and meeting the criteria set under ODA, extended by governments or official agencies, and for which repayment is required in convertible currencies or in kind. Rescheduling (maturity extension of loans originally made by a government or official agency) and loans made by a government or an official agency to refinance indebtedness due to the private or official sector, are included if reported as Official Development Assistance or Official Aid. The net data are reported after deduction of amortization payments and the impact of other measures reducing debt (e.g.forgiveness).

Technical Co-operation: This is defined as activities whose primary purpose is to augment the level of knowledge, skills, technical know-how or productive aptitudes of the population of developing countries, i.e., increasing their stock of human intellectual capital, or their capacity for more effective use of their existing factor endowment. Accordingly, the figures relate mainly to activities involving the supply of human resources (teachers, volunteers, experts in various sectors) and action targeted on human resources (education, training, advice).

Private Sector Flows: is broken down into direct investment, portfolio investment, and export credits (net). The transactions covered are those undertaken by residents of DAC Member countries. Portfolio investment corresponds to bonds and equities. In the text, flows to the private sector is divided into three: foreign direct investment, portfolio investment and other private flows (including export credits, contractual leadings). 


\section{LIST OF BILATERAL AND MULTILATERAL DONORS}

Members of the Development Assistance Committee (DAC)

Australia

Austria (EU)

Belgium (EU)

Canada

Denmark (EU)

Finland (EU)

France (EU)

Germany (EU)

Greece (EU)

Ireland (EU)

Italy (EU)

Japan

Luxembourg (EU)

Netherlands (EU)

New Zealand

Norway

Portugal (EU)

Spain (EU)

Sweden (EU)

Switzerland

United Kingdom (EU)

United States

\section{Multilateral Organizations}

Africa

AfDB- African Development Bank

AfDF- African Development Fund

Asia

AsDB- Asian Development Bank

AsDB- Asian Development Bank Special Funds

UN Agencies

UNDP- United Nations Development Program

UNFPA- United Nations Fund for Population Activities

UNHCR- United Nations High Commissioner for Refugees

UNICEF- United Nations Children's Fund

UNRWA- United Nations Relief and Works Agency for Palestine Refugees in the Near East UNTA United Nations Regular Program of Technical Assistance

WFP- World Food Program

ARAB AGENCIES Arab Agencies

IMF- International Monetary Fund

IBRD- International Bank for Reconstruction and Development

The World Bank

IFAD- International Fund for Agricultural Development

NDF- Nordic Development Fund

IDB- Inter-American Development Bank

Montreal Protocol

IFC- International Finance Corporation

EU- European Union 